\title{
Malaysian Pharmacists' Involvement in Pharmaceutical Care: A Narrative Review
}

\author{
Mahmathi Karuppannan*, Liyana Syafiqah Muhammad Syazwan Thana and Shubashini Gnanasan \\ Department of Pharmacy Practice, Faculty of Pharmacy, Universiti Teknologi MARA, Malaysia
}

*Corresponding author: Department of Pharmacy Practice, Faculty of Pharmacy, Universiti Teknologi MARA, Malaysia. E-mail: mahmathi@uitm.edu.my.

Received Date: August 19, 2019

Published Date: September 03, 2019

\section{Abstract}

Pharmacists' role has been diversified from dispensing medications to patient care. At present there is no collation of such information related to Malaysian pharmacists. This review explores the scope of involvement of pharmacists in pharmaceutical care (PC) services in Malaysia and the outcomes achieved. Articles published between 1990 - Feb 2017 were searched from Science Direct, MEDLINE (PubMed and Ovid), The Cochrane Library and Google Scholar. From 62 records, 17 articles met the selection criteria. Nine articles reported studies related to diabetes mellitus (DM); DM medication therapy adherence clinic, home medication review, patient education program and PC model. The most common services provided by the pharmacists were patient education or counselling and assessing patient's medication adherence. In 9 studies which were conducted among diabetes patients, pharmacists' intervention caused significant decrease in $\mathrm{HbA1c}$, fasting blood glucose and/or lipid profile values. While medication adherence was reported to be significantly improved in 10 studies. Pharmacist's interventions were also found to have improved patients knowledge and quality of life as reported in 5 studies. In addition 4 studies reported significant positive economic outcomes. This study revealed that Malaysian pharmacist's involvement had positive impacts in clinical, humanistic and economic outcomes. Many studies focussed on one particular medical condition - diabetes mellitus. More studies should be conducted involving pharmacists from other settings and in different patient populations.

Keywords: Pharmaceutical care; Malaysia pharmacists; Medication therapy adherence clinic (MTAC)

\section{Background}

Pharmaceutical care (PC) is defined as the responsible provision of drug therapy via collaboration of a clinical pharmacist with the patient, as well as other members of the health care team, in designing, implementing, and monitoring a therapeutic plan that will produce specific outcomes [1]. This includes identifying potential and actual drug-related problems, resolving current drugrelated problems, and preventing future drug-related problems. The roles of pharmacist in health care have expanded from product care to patient care [2]. World Health Organization (WHO) in conjunction with the International Pharmaceutical Federation (FIP) promoted an expanded role of pharmacists for the purpose of improving patient care and drug therapy outcomes [3]. Unlike decades ago, pharmacists are stepping in the front line to have direct contact with patients. The involvement of pharmacists in the health care has seen positive impacts [2]. One of the recent study indicated that the intervention of pharmacist in providing counselling to patients had positive impact on adherence towards medication and quality of life [4]. In addition, pharmacists' intervention was found to reduce errors and improve the quality of services at health institutions
[5]. In developing countries, pharmacists were identified as the predominant source of evidence-based drug information [6]. The scope of pharmacists in PC in Malaysia is quite ambiguous even though the role of pharmacists begin to change and expand from dispensing and compounding drugs to providing pharmaceutical care in the late 1990s [1]. In many cases, the possibilities of the pharmacist are not used optimally. Many studies have been done to evaluate the services or strategies pharmacists use to provide PC. To date no studies have collated all this information. The purpose of this study was to systematically review the literature on PC services provided by Malaysian pharmacists and the impact from these services.

\section{Methods}

The systematic searching in Science Direct, MEDLINE (PubMed and Ovid), The Cochrane Library and Google Scholar was conducted to identify articles published in 1990 to February 28, 2017. Reviews and meta-analyses, as well as reference lists of selected articles, were searched for relevant studies. Conference proceedings were also searched. Variety of key words were used as 
search term such as 'pharmacists', 'pharmacist roles', 'pharmacist responsibilities', 'pharmacist involvement', 'contribution of pharmacist', 'pharmacist intervention', 'pharmaceutical care services', 'pharmacist service', 'outcomes', 'benefits' , 'medication therapy adherence clinic (MTAC)', 'medical therapy management (MTM)' and 'Malaysia'. All the potential citations were reviewed by title and abstract and only relevant citations were retrieved. Two reviewers independently screened the title and abstract of all the articles to identify potentially relevant articles based on inclusion and exclusion criteria. If the abstract clearly showed that the study did not match our inclusion criteria, the study was excluded. If there was uncertainty about inclusion criteria, a full copy of the article was obtained. The primary author then reviewed the final selection of articles for completeness. The summary of the study included in this review are summarized in Table 1. The considered inclusion criteria for studies included in this review are as follows: (i) the studies published in English language; (ii) full-text articles or conference proceedings; (iii) study involved comparison groups: control group or pre-intervention (CG) and intervention group or post-intervention (IG); (iv) studies reported the measured outcomes (Table 1).

Table 1: Characteristics of Studies on Pharmaceutical Care.

\begin{tabular}{|c|c|c|c|c|c|c|}
\hline Reference & Population & Setting & $\begin{array}{l}\text { Sample } \\
\text { size }\end{array}$ & $\begin{array}{c}\text { Pharmaceutical } \\
\text { service }\end{array}$ & Interventions & Study limitations \\
\hline $\begin{array}{l}\text { 1. M.Butt et al } \\
{[7]}\end{array}$ & $\begin{array}{l}\text { Diabetes } \\
\text { mellitus }\end{array}$ & $\begin{array}{l}\text { Ambulatory } \\
\text { care clinic }\end{array}$ & $\begin{array}{c}72 \\
\text { CG: } 36 \\
\text { IG: } 36\end{array}$ & $\begin{array}{l}\text { Patient Education } \\
\text { by Pharmacist } \\
\text { Programme }\end{array}$ & $\begin{array}{l}\text { - Patient education/ } \\
\text { counselling } \\
\text { - } \\
\text { Assessment of medi- } \\
\text { cation adherence }\end{array}$ & $\begin{array}{l}\text { - } \begin{array}{c}\text { study was voluntary and do } \\
\text { not represent general diabetes } \\
\text { population. }\end{array} \\
\text { - } \quad \text { incomplete record about the } \\
\text { total number of patients and } \\
\text { reason they were excluded } \\
\text { short duration of the study } \\
\text { lack of a strict protocol for the } \\
\text { baseline clinical values } \\
\text { exclusion of patients who could } \\
\text { not understand either Malay or } \\
\text { English language }\end{array}$ \\
\hline $\begin{array}{l}\text { 2. P. C. Lim et } \\
\text { al [8] }\end{array}$ & $\begin{array}{l}\text { Diabetes } \\
\text { mellitus }\end{array}$ & $\begin{array}{l}\text { Ambulatory } \\
\text { care clinic }\end{array}$ & $\begin{array}{c}86 \\
\begin{array}{c}\text { CG: } 43 \\
\text { (pre) }\end{array} \\
\text { IG: } 43 \\
\text { (post) }\end{array}$ & $\begin{array}{l}\text { diabetes mellitus } \\
\text { medication } \\
\text { therapy adherence } \\
\text { clinic }\end{array}$ & $\begin{array}{l}\text { - } \\
\text { Patient education/ } \\
\text { counselling } \\
\text { - } \\
\text { Assessment of medi- } \\
\text { cation adherence } \\
\text { - } \quad \text { Dosage adjustments } \\
\text { Addition of medica- } \\
\text { tions }\end{array}$ & $\begin{array}{l}\text { - } \quad \text { retrospective review } \\
\text { - } \quad \text { shall population } \\
\text { - } \quad \text { there was no control group }\end{array}$ \\
\hline $\begin{array}{l}\text { 3. W. W.Chung et } \\
\text { al. [9] }\end{array}$ & $\begin{array}{l}\text { Diabetes } \\
\text { mellitus }\end{array}$ & $\begin{array}{l}\text { Ambulatory } \\
\text { care clinic }\end{array}$ & $\begin{array}{l}241 \\
\text { CG: } 121 \\
\text { IG: } 120\end{array}$ & $\begin{array}{l}\text { pharmaceutical } \\
\text { care model on } \\
\text { medication adher- } \\
\text { ence and glycemic } \\
\text { control }\end{array}$ & $\begin{array}{l}\text { - } \quad \begin{array}{c}\text { Patient education/ } \\
\text { counselling }\end{array} \\
\text { - } \quad \begin{array}{c}\text { Assessment of medi- } \\
\text { cation adherence }\end{array} \\
\text { - } \quad \text { Medication review }\end{array}$ & $\begin{array}{l}\text { Exclusion of patients who } \\
\text { could not understand English } \\
\text { language. } \\
\text { single center } \\
\text { cross-contamination between } \\
\text { participants in the control and } \\
\text { intervention groups attending } \\
\text { the same clinic } \\
\text { short duration of the study }\end{array}$ \\
\hline $\begin{array}{l}\text { 4. L. Anchah et } \\
\text { al. [10] }\end{array}$ & $\begin{array}{l}\text { acute } \\
\text { coronary } \\
\text { syndrome }\end{array}$ & $\begin{array}{l}\text { Ambulatory } \\
\text { care clinic }\end{array}$ & $\begin{array}{l}112 \\
\text { CG: } 62 \\
\text { IG: } 50\end{array}$ & $\begin{array}{l}\text { cardiac rehabili- } \\
\text { tation }\end{array}$ & $\begin{array}{c}\text { - Patient education/ } \\
\text { counselling }\end{array}$ & - $\quad$ single center \\
\hline $\begin{array}{l}\text { 5. P. C. Lim et al. } \\
\text { [11] }\end{array}$ & $\begin{array}{l}\text { Diabetes } \\
\text { mellitus }\end{array}$ & $\begin{array}{l}\text { Ambulatory } \\
\text { care clinic }\end{array}$ & $\begin{array}{c}76 \\
\text { CG: } 37 \\
\text { IG: } 39\end{array}$ & $\begin{array}{l}\text { diabetes mellitus } \\
\text { medication } \\
\text { therapy adherence } \\
\text { clinic }\end{array}$ & $\begin{array}{l}\begin{array}{c}\text { Patient education/ } \\
\text { counselling }\end{array} \\
\text { - } \\
\text { Assessment of medi- } \\
\text { cation adherence } \\
\text { - } \\
\text { Dosage adjustments } \\
\text { Addition of medica- } \\
\text { tions } \\
\text { - }\end{array}$ & $\begin{array}{l}\text { - } \quad \text { small population } \\
\text { - } \quad \text { short duration of the study }\end{array}$ \\
\hline
\end{tabular}




\begin{tabular}{|c|c|c|c|c|c|c|}
\hline $\begin{array}{l}\text { 6. U. Periasamy } \\
\text { et al. [12] }\end{array}$ & $\begin{array}{l}\text { Cancer pa- } \\
\text { tients }\end{array}$ & $\begin{array}{l}\text { Oncology } \\
\text { department }\end{array}$ & $\begin{array}{l}162 \\
\text { CG: } 81 \\
\text { IG: } 81\end{array}$ & $\begin{array}{l}\text { chemotherapy } \\
\text { counseling }\end{array}$ & $\begin{array}{l}\text { - Patient education/ } \\
\text { counselling }\end{array}$ & $\begin{array}{l}\text { - } \quad \text { patients' symptoms were self-re } \\
\text { ported subject to recall bias }\end{array}$ \\
\hline $\begin{array}{l}\text { 7. P. S. M. Lai et } \\
\text { al. [13] }\end{array}$ & $\begin{array}{l}\text { postmeno- } \\
\text { pausal } \\
\text { osteoporotic } \\
\text { women }\end{array}$ & $\begin{array}{l}\text { Ambulatory } \\
\text { care clinic }\end{array}$ & $\begin{array}{c}198 \\
\text { CG: } 98 \\
\text { IG: } 100\end{array}$ & $\begin{array}{l}\text { Pharmaceutical } \\
\text { care in postmeno- } \\
\text { pausal osteoporot- } \\
\text { ic women }\end{array}$ & $\begin{array}{l}\text { - } \\
\text { Patient education/ } \\
\text { counselling } \\
\text { - } \\
\text { Assessment of medi- } \\
\text { cation adherence } \\
\text { - } \quad \text { Medication review }\end{array}$ & - $\quad$ Single center \\
\hline $\begin{array}{c}\text { 8. Y. Hassan et al } \\
\text { [14] }\end{array}$ & $\begin{array}{l}\text { acute } \\
\text { coronary } \\
\text { syndrome }\end{array}$ & $\begin{array}{l}\text { Ambulatory } \\
\text { care clinic }\end{array}$ & $\begin{array}{c}380 \\
\text { CG: } 190 \\
\text { (pre) } \\
\text { IG: } 190 \\
\text { (post) }\end{array}$ & $\begin{array}{l}\text { pharmacist-initiat- } \\
\text { ed interventions }\end{array}$ & $\begin{array}{lc}\text { - } & \text { Assessment of medi- } \\
\text { cation adherence } \\
\text { - } & \text { Dosage adjustments } \\
\text { - } & \begin{array}{c}\text { Addition of medica- } \\
\text { tions }\end{array} \\
\text { - } & \text { Medication review } \\
\text { - } & \text { Change of medica- } \\
\text { tions }\end{array}$ & - $\quad$ short duration of the study \\
\hline $\begin{array}{l}\text { 9. P. S. M. Lai et } \\
\text { al, [15] }\end{array}$ & $\begin{array}{l}\text { postmeno- } \\
\text { pausal women } \\
\text { with osteopo- } \\
\text { rosis }\end{array}$ & $\begin{array}{l}\text { Ambulatory } \\
\text { care clinic }\end{array}$ & $\begin{array}{c}198 \\
\text { CG: } 98 \\
\text { IG: } 100\end{array}$ & $\begin{array}{l}\text { Pharmaceutical } \\
\text { care in postmeno- } \\
\text { pausal osteoporot- } \\
\text { ic women }\end{array}$ & $\begin{array}{l}\text { - } \quad \begin{array}{c}\text { Patient education/ } \\
\text { counselling }\end{array} \\
\text { - } \quad \text { Medication review }\end{array}$ & - $\quad$ Single center \\
\hline $\begin{array}{l}\text { 10. Y. Hassan et } \\
\text { al. [16] }\end{array}$ & $\begin{array}{l}\text { Chronic Kid- } \\
\text { ney Disease }\end{array}$ & $\begin{array}{l}\text { Nephrology } \\
\text { unit }\end{array}$ & $\begin{array}{l}600 \\
\text { CG: } 300 \\
\text { (pre) } \\
\text { IG: } 300 \\
\text { (post) }\end{array}$ & $\begin{array}{l}\text { Renal Drug Dosing } \\
\text { Service }\end{array}$ & - $\quad$ Dosage adjustments & $\begin{array}{l}\text { - an overestimation of ADEs } \\
\text { underestimation of pharma- } \\
\text { coeconomic impact of the } \\
\text { intervention }\end{array}$ \\
\hline $\begin{array}{l}\text { 11. S. T. R. Zaidi } \\
\text { et al [17] }\end{array}$ & ICU patients & ICU & $\begin{array}{l}\text { Not } \\
\text { related }\end{array}$ & $\begin{array}{l}\text { Pharmacist rec- } \\
\text { ommendations }\end{array}$ & $\begin{array}{cc}\text { - } & \text { Dosage adjustments } \\
\text { - } & \text { Addition of medica- } \\
\text { tions } \\
\text { - } & \text { Change of medica- } \\
\text { tions }\end{array}$ & - $\quad$ None \\
\hline $\begin{array}{l}\text { 12. E. P. Chow } \\
\text { et al } \\
{[18]}\end{array}$ & $\begin{array}{c}\text { Diabetes } \\
\text { mellitus }\end{array}$ & $\begin{array}{l}\text { Patient } \\
\text { home }\end{array}$ & $\begin{array}{l}150 \\
\text { CG: } 75 \\
\text { IG: } 75\end{array}$ & $\begin{array}{l}\text { home medication } \\
\text { review }\end{array}$ & $\begin{array}{l}\text { - } \begin{array}{c}\text { Patient education/ } \\
\text { counselling }\end{array} \\
\text { - } \quad \text { Assessment of medi- } \\
\text { cation adherence } \\
\text { - } \quad \text { Medication review }\end{array}$ & - $\quad$ none \\
\hline $\begin{array}{l}\text { 13. A. Nor Elina } \\
\text { et al [19] }\end{array}$ & $\begin{array}{l}\text { diabetes } \\
\text { mellitus }\end{array}$ & $\begin{array}{l}\text { Patient } \\
\text { home }\end{array}$ & $\begin{array}{c}73 \\
\text { CG: } 35 \\
\text { IG: } 38\end{array}$ & $\begin{array}{l}\text { home medication } \\
\text { review }\end{array}$ & $\begin{array}{l}\text { - } \\
\begin{array}{c}\text { Patient education/ } \\
\text { counselling }\end{array} \\
\text { - } \\
\begin{array}{c}\text { Assessment of medi- } \\
\text { cation adherence }\end{array} \\
\text { - } \\
\text { Medication review }\end{array}$ & - none \\
\hline $\begin{array}{l}\text { 14. E. P. Chow et } \\
\text { al. [20] }\end{array}$ & $\begin{array}{l}\text { diabetes } \\
\text { mellitus }\end{array}$ & $\begin{array}{l}\text { Patient } \\
\text { home }\end{array}$ & $\begin{array}{l}150 \\
\text { CG: } 75 \\
\text { IG: } 75\end{array}$ & $\begin{array}{l}\text { Home Medication } \\
\text { Review }\end{array}$ & $\begin{array}{l}\text { - } \\
\begin{array}{c}\text { Patient education/ } \\
\text { counselling }\end{array} \\
\text { - } \\
\begin{array}{c}\text { Assessment of medi- } \\
\text { cation adherence }\end{array} \\
\text { - } \\
\text { Medication review }\end{array}$ & - $\quad$ none \\
\hline $\begin{array}{l}\text { 15. P. S. Tan et al } \\
\text { [21] }\end{array}$ & $\begin{array}{l}\text { diabetes } \\
\text { mellitus }\end{array}$ & $\begin{array}{l}\text { Ambulatory } \\
\text { care clinic }\end{array}$ & $\begin{array}{c}222 \\
\text { CG: } 111 \\
\text { IG: } 111\end{array}$ & $\begin{array}{l}\text { diabetes mellitus } \\
\text { medication } \\
\text { therapy adherence } \\
\text { clinic }\end{array}$ & $\begin{array}{l}\text { - Patient education/ } \\
\text { counselling } \\
\text { - } \\
\text { Assessment of medi- } \\
\text { cation adherence }\end{array}$ & - none \\
\hline $\begin{array}{l}\text { 16. S. K. Hu et al. } \\
\text { [22] }\end{array}$ & Hypertension & $\begin{array}{l}\text { Ambulatory } \\
\text { care clinic }\end{array}$ & $\begin{array}{c}70 \\
\text { CG: } 35 \\
\text { IG: } 35\end{array}$ & $\begin{array}{l}\text { Pharmacist-Assist- } \\
\text { ed Hypertension } \\
\text { Clinic on Health- } \\
\text { care System }\end{array}$ & $\begin{array}{l}\text { - Patient education/ } \\
\text { counselling } \\
\text { - } \\
\text { Assessment of medi- } \\
\text { cation adherence }\end{array}$ & - none \\
\hline
\end{tabular}




\begin{tabular}{|c|c|c|c|c|c|c|}
\hline $\begin{array}{c}\text { 17. N. K. Loga- } \\
\text { nadan et al } \\
{[23]}\end{array}$ & $\begin{array}{c}\text { diabetes } \\
\text { mellitus }\end{array}$ & $\begin{array}{c}\text { Ambulatory } \\
\text { care clinic }\end{array}$ & $\begin{array}{c}\text { CG: } 42 \\
\text { IG: } 43\end{array}$ & $\begin{array}{c}\text { diabetes mellitus } \\
\text { medication } \\
\text { therapy adherence } \\
\text { clinic }\end{array}$ & $\begin{array}{c}\text { Patient education/ } \\
\text { counselling } \\
\text { Assessment of medi- } \\
\text { cation adherence }\end{array}$ & None \\
\hline
\end{tabular}

\section{Results}

The literature search yielded 62 articles. From these 62 citations, 2 studies were removed due to duplication and 24 studies were excluded after screening the title and abstract (Figure 1). 19 studies were excluded after full text screening because they did not meet the inclusion criteria for example the intervention was conducted by non-pharmacist, the study was conducted outside Malaysia and the outcome was not reported. 17 studies met the inclusion criteria and were therefore selected for analysis. The 17 studies included in this review were published between 2003 and 2017 [7-23]. There were 11 full journal articles [7-17] among the 17. Pharmacists were found to be involved in PC services related to diabetes mellitus (DM) more commonly compared to other medical conditions. DM medication therapy adherence clinic (MTAC) [8,11,21,23], home medication review [18-20], patient education program [7] and PC model [9] involving type 2 DM patients were the most common services provided by Malaysian pharmacists. Other services provided by pharmacists involved patient population with acute coronary syndrome [10,14], cancer [12], postmenopausal osteoporosis [13,15], chronic kidney disease [16], ICU [17] and hypertension [22]. In these services, pharmacists play major role in educating patients [7-11,13,15,1823]; assessing their medication adherence [7-9,11,13,18-20,22,23] and conducting medication review [18-20]. In terms of practice settings, 14 studies were conducted in hospital settings [7-17,21$23]$ whilst 3 were conducted in patient homes [18-20]. Sample size ranged from a minimum of 70 patients [22] to a maximum of 600 [16] and 6 studies [7, 8,11,19, 22,23] had sample sizes smaller than 100. All articles evaluated many outcomes that were classified as Clinical: HbA1c (9 studies) [7-9, 11,18-20,22,23], FBS (6 studies) [7-9,11,19,20] lipid profile (5 studies) [7,8,11,19,20], BP (2 studies) $[19,22]$, body mass index (2 studies) $[7,11]$, bone turnover makers (BTM) (1 study) [13]; Humanistic: medication adherence (10 studies) [7-9,11,13,18-20,22,23], quality of life (QoL) (4 studies) $[7,10,15,19]$, patient satisfaction (2 studies) $[15,20]$, knowledge (5 studies) [12,15,18,20,22], self-esteem (1 study) [12]; and Economic (5 studies) [16,17,20,21,23] (Figure 1).

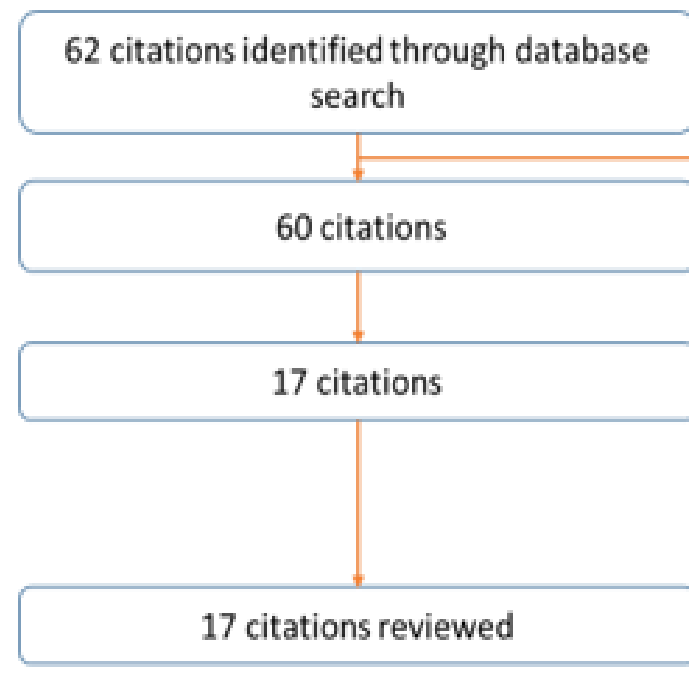

Excluded:

24 studies were excluded after screening the title and abstract

19 studies were excluded because they did not meet the inclusion criteria

Figure 1: Flow chart of abstract and article selection.

Table 2: The impact of pharmacists' intervention.

\begin{tabular}{|c|c|c|}
\hline Reference & Outcomes measured (tools) & Impacts \\
\hline 1. M.Butt et al [7] & $\begin{array}{l}\text { HbA1c, BMI, lipid profile, Medication adherence, (MMMAS), QoL } \\
\text { (EQ-5D-3L) }\end{array}$ & $\begin{array}{l}\text { Humanistic } \\
\text { - } \quad \text { Improved medication adherence } \\
\text { - } \quad \text { Reduction in HbA1c level } \\
\text { - } \quad \text { Reduction in BMI } \\
\text { - No significant changes in lipid profile }\end{array}$ \\
\hline
\end{tabular}




\begin{tabular}{|c|c|c|c|}
\hline 2. & P. C. Lim et al [8] & HbA1c, FBG, lipid profile, Medication Adherence (MMMAS) & $\begin{array}{l}\text { Humanistic } \\
\text { - Improved medication adherence } \\
\text { Clinical } \\
\text { - Reduction in HbA1c level } \\
\text { - Reduction in FBG } \\
\text { - Reduction of mean TG was not significant. } \\
\text { Reduction of mean HDL cholesterol was not signif- } \\
\text { icant. }\end{array}$ \\
\hline & $\begin{array}{l}\text { W. W. Chung et } \\
\text { al. [9] }\end{array}$ & HbA1c, FBG, levels and, Medication adherence (MALMAS) & $\begin{array}{c}\text { Humanistic } \\
\text { - Improved medication adherence } \\
\text { Clinical } \\
\text { - Reduction in HbA1c level } \\
\text { - Reduction in fasting blood glucose }\end{array}$ \\
\hline 4. & $\begin{array}{l}\text { L. Anchah et al. } \\
\qquad[10]\end{array}$ & QoL (SF-36) & $\begin{array}{c}\text { Humanistic } \\
\text { - Increased physical, psychological and social recovery } \\
\text { - } \quad \text { Reduced anxiety } \\
\text { - } \quad \text { Improved QoL }\end{array}$ \\
\hline 5. & $\begin{array}{l}\text { P. C. Lim et al. } \\
{[11]}\end{array}$ & $\begin{array}{l}\text { HbA1c, FBG, BMI, blood pressure, lipid profile, medication Adher- } \\
\text { ence (MMMAS) }\end{array}$ & $\begin{array}{l}\text { Humanistic } \\
\text { - Improved medication adherence } \\
\text { Clinical } \\
\text { - Reduction in fasting blood glucose } \\
\text { - Reduction in mean total cholesterol } \\
\text { - Ro significant changes in the TG and HDL cholesterol } \\
\text { - Reduction in mean systolic blood pressure } \\
\text { - No significant changes in BMI }\end{array}$ \\
\hline 6. & $\begin{array}{l}\text { U. Periasamy et } \\
\text { al. [12] }\end{array}$ & $\begin{array}{l}\text { Patient Health Questionnaire-9 (PHQ-9), Generalized } \\
\text { Anxiety Disorder-7 (GAD-7) and Rosenberg Self-Esteem Scale. }\end{array}$ & $\begin{array}{c}\text { Humanistic } \\
\qquad \quad \text { Reduced anxiety } \\
\bullet \quad \text { Reduction in severity of depression } \\
\text { • Increased self-esteem }\end{array}$ \\
\hline & $\begin{array}{l}\text { P. S. M. Lai et al. } \\
\qquad \text { [13] }\end{array}$ & $\begin{array}{l}\text { Medication adherence direct-reporting, pill count and } \\
\text { self-recording, BTMs and persistence (defined as the time in days } \\
\text { from the date of the first dose of bisphosphonate until discontinu- } \\
\text { ation of treatment) }\end{array}$ & $\begin{array}{c}\text { Humanistic } \\
\text { - Medication adherence: } \\
\circ \quad \text { Direct reporting: no significant difference } \\
\circ \quad \text { Pill counting: higher adherence } \\
\circ \quad \text { Self-recording: higher adherence } \\
\text { - Persistence: high and similar between both groups }\end{array}$ \\
\hline
\end{tabular}




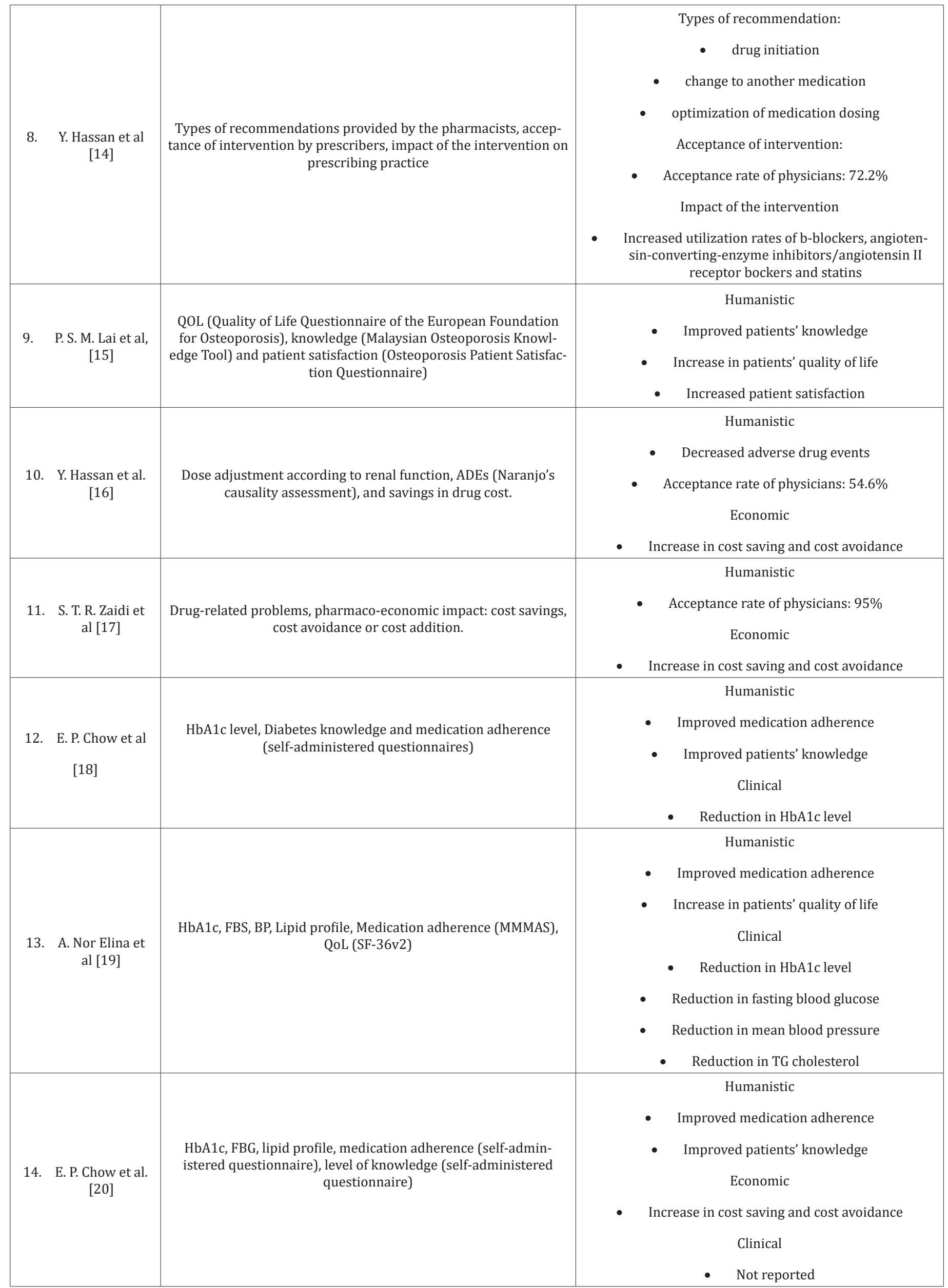




\begin{tabular}{|c|c|c|}
\hline $\begin{array}{l}\text { 15. P. S. Tan et al } \\
{[21]}\end{array}$ & HbA1c and economic outcomes & $\begin{array}{c}\text { Clinical } \\
\text { - Reduction in HbA1c level } \\
\text { Economic } \\
\text { - Increase in cost saving and cost avoidance }\end{array}$ \\
\hline $\begin{array}{l}\text { 16. S. K. Hu et al. } \\
{[22]}\end{array}$ & Morisky Scores, blood pressure, knowledge & $\begin{array}{c}\text { Humanistic } \\
\text { - Improved medication adherence } \\
\text { - Improved patients' knowledge } \\
\text { Clinical } \\
\text { - Reduction in mean systolic blood pressure }\end{array}$ \\
\hline $\begin{array}{c}\text { 17. N. K. Loganadan } \\
\text { et al } \\
{[23]}\end{array}$ & HbA1c, Morisky Scores, cost-effectiveness analysis (CEA). & $\begin{array}{c}\text { Humanistic } \\
\text { - Improved medication adherence } \\
\text { Clinical } \\
\text { - Reduction in HbA1c level } \\
\text { Economic } \\
\text { - Increase in cost saving and cost avoidance }\end{array}$ \\
\hline
\end{tabular}

The 10 articles which evaluated medication adherence utilized the Modified Morisky Medication Adherence Score (MMMAS) [7,8,11,19], Malaysian Medication Adherence Score (MALMAS) [9], Morisky score (no mention of the tool) [22,23], self-administered questionnaire (no mention of the tool) (2) $[8,20]$ and combination of patient direct reporting, pill counting and self-recording [13]. All studies reported improvement in the adherence except the study by Lai et al (2011) [13]. In this study when direct-reporting was used, no significant differences were found between control and intervention group. However significant differences were found when pill-counting and self-record were taken into account. Since pill counting was only able to determine if the patient took the medication within that week or month and not on a particular day, researcher applied results from self-recording for subsequent analyses. Clinical outcomes in majority of the articles were found to have decreased: HbA1c [7-9,11,18-20,22,23] and full blood glucose (FBG) [7-9,11,19,20]. More details are shown in Table 2. However the outcomes on lipid profile showed mixed results [7,8,11,19]. All humanistic outcomes showed improvement except no changes seen in QoL in a study by Butt et al (2016) [7] and economic outcomes showed increase in cost saving and cost avoidance [16,17,20,21,23]. In studies where pharmacists provided recommendation on drug treatments $[14,16,17]$, the acceptance rate of physicians ranged between $55 \%$ and $95 \%$. The types of recommendation given by pharmacists were drug initiations [14,17], change to another medication [14,17], and optimization of medication dosing $[14,16,17]$ (Table 2).

\section{Discussion}

This is the first review to examine the impact of Malaysian pharmacists' involvement in PC. Our results indicated that there are few studies on this topic, with most of them being published from 2010. The concept of PC was first introduced in 1990 [1]. Only after more than a decade did studies in Malaysia were published.
Besides, MTAC was first initiated in 2004 [24,25]. The first being post-renal transplants MTAC, while DM MTAC was first introduced in 2006. The number of MTACs gradually increased and saw an escalation in 2010 (187 in 2009 versus 390 in 2010) and 2011 (561 MTACs). To date there are 839 MTACs all over Malaysia [25]. Initiation of these clinics offered opportunities for pharmacists to provide PC to patients and explains the continuous publication of articles related to MTAC after 2010.

PC in Malaysia seems to be focusing on one type of medical conditions. About half of the articles involved type 2 DM population (52\%). DM is a global problem. The prevalence of DM in Malaysia is in a rising trend, from $11.6 \%$ in 2006 to $17.5 \%$ in 2015 [26] causing an alarm to all health care providers. Thus, more programs are introduced to help DM patients to manage their conditions. Yet, the prevalence of hypertension, cardiovascular diseases, decline in mental health and other conditions are also on the rise [26]. Patients from these populations should also be considered for PC as their QoL may also be affected by these diseases and further add to the health care burden. In addition to that, pharmacists should also be involved in promoting health especially in community pharmacy, which is a conducive setting for patient-pharmacist communication [27]. Most studies in this review were conducted in the ambulatory care clinics. PC are usually successful in this setting because there is better communication between health care professionals, leading to better patient outcomes [28]. Pharmacists in these settings are able to work closely with physicians and a multidisciplinary team is an effective approach. A systematic review on the effects of pharmacists' interventions showed that pharmacists ensured continuity of care by having on-going relationships with other health care professionals and served as a 'bridge' between these health care professionals and the patients [29]. In addition, pharmacists provided recommendations to patients and their health care professionals to optimize therapeutic outcomes. Another review indicated that pharmacists working in partnership 
with other health care professionals or in a collaborative-practice model were able to contribute to improved patient outcomes [30].

One of the criteria pharmacists should have before providing PC is "to develop relationships with the patient and other healthcare providers that are needed in the provision of PC'.[1]. This may not be the case in community pharmacy settings especially in Malaysia where community pharmacists work independently and hence are underutilized. Nevertheless, efforts should be taken to increase the acceptability of pharmacists role in primary setting [31] and to initiate collaboration between community pharmacists and general practitioners. A study conducted in Malaysia showed that community pharmacists are providing some services related to PC [32] but further investigation is needed to evaluate the effectiveness of these services [33]. Despite that barriers to implementing PC in community pharmacy do exist - lack of skills, time, staff and motivation $[34,35]$ which could hinder pharmacists from providing PC services. The involvement of pharmacists showed significant improvement in clinical, humanistic and economic outcomes. Beneficial reductions was seen in modifiable risk factors, most notably glycemic control [7-9,11,18-21,23] and blood pressure $[11,19,22]$. Participation of the pharmacists also had a positive impact on medication adherence [7-9,11,13,18-20,22,23] and QoL $[10,15,19]$. On top of that, pharmacists' involvement produced significant cost savings and cost avoidance [16,17,20,21,23]. Similarly a comprehensive PC program (consisting of patient education and advice on medication adherence, metabolic control and life style) delivered by a clinical pharmacist over a 12-month period in United Arab Emirates revealed significantly improved glycaemic control and health-related quality of life [36]. Other studies have also reported positive outcomes with the involvement of pharmacists $[4,37,38]$. It is without doubt that pharmacists are essential healthcare professionals who enhance patient care and promote wellness.

Implementation of a large-scale study still appears to be lacking, despite the positive outcomes of most studies. Results on the effectiveness of health services must be based on long-term follow-up as the sustainability of an intervention on long-term needs further investigations. Most of studies had smaller sample size and recruited by the researcher. A larger study involving multidisciplinary team and blinding the recruitment process could provide a better picture of the effectiveness of PC services in Malaysia. As mentioned by Helper and Strand [1], PC involves a teamwork and a two-way communication with patients. Thus, multidisciplinary approach in PC should be encouraged. For PC to be successful in the community setting, community pharmacists should be encouraged to play their part. Although PC may be practiced in Malaysia, little is known of its effectiveness in the producing positive outcomes. It is also important to know if the community pharmacists are ready in terms of skills, staff and facilities to implement PC. These could be an area for future studies. All the studies in this review supported patients who have chronic, uncontrolled medical conditions. Newly diagnosed population, who upon diagnosis may feel confused and at denial, needs the support from health care professionals. Tackling their issues at early stage may reduce the severity of the medical conditions. PC services can be implemented in this patient population and how these services prevent further worsening of the medical conditions should be investigated.

\section{Limitations of the Study}

There are some limitations in this research. Search was limited to studies published in English and, hence, studies conducted in other languages might be overlooked. Moreover, the patient populations varied greatly between the studies and some of the studies had small sample sizes which may affect the outcomes. Selection bias may have occurred during article searching as the keywords used are more to positive words such as 'benefit' and 'contribution'. In spite of these limitations, this study gives an overview of the PC activities conducted by pharmacists in Malaysia and provides suggestions for future area of research.

\section{Conclusion}

This review highlighted numerous roles of Malaysian pharmacists in pharmaceutical care and showed that pharmacist intervention resulted in various positive outcomes. Clinical, humanistic and economic outcomes were mostly seen to have improved with the involvement of pharmacists. The common site of study was hospital and more study should be encouraged in other settings especially the community pharmacy. Diabetes mellitus was the main focus in many study suggesting future studies to be enhanced in other populations.

\section{Conflict of Interest}

\section{None}

\section{Ethical Approval}

The research project received institutional ethical approval from Research Ethics Committee (REC) of Universiti Teknologi MARA (UiTM).

\section{References}

1. Hepler CD, LM Strand (1990) Opportunities and responsibilities in pharmaceutical care. Am J Hosp Pharm 47(3): 533-543.

2. Al Jumah KA, NA Qureshi (2012) Impact of pharmacist interventions on patients' adherence to antidepressants and patient-reported outcomes: a systematic review. Patient preference and adherence 6: 87-100.

3. Joint FIP/WHO guidelines on good pharmacy practice: standards for quality of pharmacy services, in WHO Technical Report Series. 2011, World Health Organization: Geneva.

4. Al Rahbi HAM, RM Al Sabri, HR Chitme (2014) Interventions by pharmacists in out-patient pharmaceutical care. Saudi Pharmaceutical Journal 22(2): 101-106.

5. Cohen V, Jellinek SP, Hatch A, Motov S (2009) Effect of clinical pharmacists on care in the emergency department: A systematic review. American Journal of Health-System Pharmacy 66(15): 1353-1361.

6. Jin X, Azhar S, Murtaza G, Xue F, Mumtaz A, et al. (2014) Quantitative study evaluating perception of general public towards role of pharmacist in health care system of Pakistan. Acta Pol Pharm 71(5): 869-875.

7. Butt M, Mhd Ali A, Bakry MM, Mustafa N (2016) Impact of a pharmacist led diabetes mellitus intervention on $\mathrm{HbA1c}$, medication adherence and quality of life: A randomised controlled study. Saudi Pharm J 24(1): 4048. 
8. Lim PC, K Lim (2010) Evaluation of a pharmacist-managed diabetes medication therapy adherence clinic. Pharmacy Practice 8(4): 250-254.

9. Chung WW, Chua SS2, Lai PS3, Chan SP (2014) Effects of a pharmaceutical care model on medication adherence and glycemic control of people with type 2 diabetes. Patient Prefer Adherence 8: 1185-1194.

10. Anchah L, Mohamed Azmi Hassali, Melissa Siaw Han Lim, Mohamed Izham Mohamed Ibrahim, Kui Hian Sim, et al. (4017) Health related quality of life assessment in acute coronary syndrome patients: the effectiveness of early phase I cardiac rehabilitation. Health and Quality of Life Outcomes 15: 10.

11. Lim PC, Lim K, Embee ZC, Hassali MA, Thiagarajan A, et al. (2016) Study investigating the impact of pharmacist involvement on the outcomes of diabetes medication therapy adherence program Malaysia. Pak J Pharm Sci 29(2): 595-601

12. Ummavathy P, Sherina MS, Rampal L, Siti Irma Fadhilah I (2015) Outcome of chemotherapy counseling by pharmacists on psychological effects and self esteem among oncology patients in a Government Hospital in Malaysia. Med J Malaysia 70(3): 131-141.

13. Lai PS, Chua SS, Chew YY, Chan SP (2011) Effects of pharmaceutical care on adherence and persistence to bisphosphonates in postmenopausal osteoporotic women. J Clin Pharm Ther 36(5): 557-567.

14. Hassan Y, Kassab Y, Abd Aziz N, Akram H, Ismail O (2013) The impact of pharmacist-initiated interventions in improving acute coronary syndrome secondary prevention pharmacotherapy prescribing upon discharge. J Clin Pharm Ther 38(2): 97-100.

15. Lai PS, Chua SS, Chan SP (2013) Impact of pharmaceutical care on knowledge, quality of life and satisfaction of postmenopausal women with osteoporosis. Int J Clin Pharm 35(4): 629-37.

16. Hassan Y, Al Ramahi RJ, Aziz NA, Ghazali R (2009) Impact of a renal drug dosing service on dose adjustment in hospitalized patients with chronic kidney disease. Ann Pharmacother 43(10): 1598-1605.

17. Zaidi ST, Hassan Y, Postma MJ, Ng SH (2003) Impact of pharmacist recommendations on the cost of drug therapy in ICU patients at a Malaysian hospital. Pharm World Sci 25(6): 299-302.

18. Chow EP, Mohamed Azmi Hassali, F Saleem, Rohit Kumar (2015) Assessment Of Pharmacist-Led Home-Based Educational Intervention Among Type 2 Diabetes Patients In The State of Penang, Malaysia. Value Health 18(7): A866.

19. Nor Elina A, MZ Che Suraya, PA Ball (2014) The Impact of Home Medication Review In Patients With Type 2 Diabetes Mellitus Living In Rural Areas Of Kuantan, Malaysia. Value in Health 17(3): A127.

20. Chow EP, A Hassali (2014) Medication Counseling Beyond Instituitional: Impact Of Pharmacist-Led Home Medication Review In Type 2 Diabetes Patients. Value in Health 17(7): A746.

21. Tan PS, T Pt (2011) Pharmacoeconomic Evaluation of a PharmacistManaged Diabetes Clinic. Value in Health 14(3): A97.

22. Hu SKN YP, Lee SW, Lee Y F, Liam KT (2010) To Investigate the Impact of Pharmacist-Assisted Hypertension Clinic on Healthcare System (IMPRESS). Medical Journal Malaysia 65.

23. K Loganadan N, KY Lim, N Mohd Nur (2012) Cost-Effectiveness of Pharmacist Managed Medication Therapy Adherence Clinic (MTAC) on Type 2 Diabetes Patients in a Tertiary Hospital in Malaysia. American College of Clinical Pharmacy Annual Meeting US.
24. Alrasheedy AA, Hassali MA, Wong ZY, Saleem F (2017) Pharmacistmanaged medication therapy adherence clinics: The Malaysian experience. Research in Social and Administrative Pharmacy 13(4): 885-886.

25. Bahri, S., Medication Therapy Adherence Clinic Services In Malaysia, in 21st National Public Health Colloquium. 2017, Department of Community Health,Faculty of Medicine, Chancellor Tuanku Muhriz Hospital, Universiti Kebangsaan Malaysia Medical Centre: Bandar Baru Bangi, Selangor, Malaysia. p. 5.

26. National Health and Morbidity Survey, in Non-Communicable Diseases, Risk Factors \& Other Health Problems, M.F.M.Y. Tahir Aris, Abdul Aiman Abd Ghani, Noor Ani Ahmad, Mohd Azahadi Omar, Tee Guat Hiong, Nur Hazwani Mohd Hasri, Nur Fadzilla Mohd Radzi, Nur Syazwani Manan, Nurul Aini Kamaruddin., Editor. 2015.

27. Nakamura CA, Luciano Soares, Mareni Rocha Farias, Silvana Nair Leite (2014) Pharmaceutical services and health promotion: how far have we gone and how are we faring? Scientific output in pharmaceutical studies. Brazilian Journal of Pharmaceutical Sciences 50(4): 773-782.

28. Hepler CD (1996) Pharmaceutical care. Pharmacy World and Science 18(6): 233-235

29. Wubben DP, EM Vivian (2008) Effects of pharmacist outpatient interventions on adults with diabetes mellitus: a systematic review. Pharmacotherapy 28(4): 421-436.

30. Armor BL, Britton ML, Dennis VC, Letassy NA (2010) A review of pharmacist contributions to diabetes care in United States. Journal of Pharmacy Practice 23(3): 250-264.

31. Azmi S, Nazri N, Azmi AH (2012) Extending the roles of community pharmacists: views from general medical practitioners. Medical Journal of Malaysia 67(6): 577-581.

32. Thamby Sam A, T Hanbrasi Jothy, S Parasuraman (2015) Assessment of Pharmaceutical Care Services Provided by a Community Pharmacy in Kedah, Malaysia 1: 73-80.

33. Wermeille J, Bennie M, Brown, McKnight J (2004) Pharmaceutical care model for patients with type 2 diabetes: integration of the community pharmacist into the diabetes team - a pilot study. Pharmacy World and Science 26(1): 18-25.

34. Mohammed Ghazal Rana Mohammed Ghazal R (2014) Barriers to the implementation of Pharmaceutical Care into the UAE community pharmacies 4: 68-74.

35. Mehralian G, Rangchian M, Javadi A, Peiravian F (2014) Investigation on barriers to pharmaceutical care in community pharmacies: a structural equation model. International Journal of Clinical Pharmacy 36(5): p. 1087-1094.

36. Al Mazroui NR, Kamal MM, Ghabash NM, Yacout TA, Kole PL, et al. (2009) Influence of pharmaceutical care on health outcomes in patients with type 2 diabetes mellitus. British Journal of Clinical Pharmacology 67(5): 547-557.

37. Davis TM, Rhonda M Clifford, Wendy A Davis, Kevin T Batty (2005) The role of pharmaceutical care in diabetes management. British Journal of Diabetes and Vascular Disease 5(6): 352-356.

38. Inamdar S, R Kulkarni (2016) Impact of Pharmaceutical Care in the Management of Drug Related Problems and Complications in the Treatment of Type II Diabetes Mellitus: A Review. Journal of Diabetology $7(1): 4-4$. 